\title{
Original article \\ Lower limb muscle coactivation levels in healthy younger and older adults during functional dual-task gait
}

\author{
Camilla Zamfolini Hallal \\ Nise Ribeiro Marques \\ São Paulo State University, Brazil \\ Edgar Ramos Vieira \\ Denis Brunt \\ Florida International University, USA \\ Deborah Hebling Spinoso \\ Alex Castro \\ Adalgiso Coscrato Cardozo \\ Mauro Gonçalves \\ São Paulo State University, Brazil
}

\begin{abstract}
The purpose of this study was to investigate the influence of daily cognitive task on stiffness of old and young female adults during the gait. The study included 17 physically active younger and 18 older women, with low risk of falls. The volunteers were asked to walk on the treadmill at two different gait conditions: normal gait and functional dual-task gait. The electromyographic signals were collected of the lower limb muscles. The percentage of coactivation for the tibialis anterior/gastrocnemius lateralis and tibialis anterior/soleus were significantly higher in elderly than in younger in the normal gait and dual-task gait. Our results suggest that the elderly have a greater stiffness in the ankle joint during gait normal and daily dual task gait. Thus, we conclude that challenging cognitively situations during the gait may increase the risk of falls in this population.
\end{abstract}

Keywords: elderly, gait, coactivation, falls

Resumo- - "Coativação muscular dos membros inferiores de jovens e idosas saudáveis durante marcha com dupla tarefa funcional." O objetivo deste estudo foi investigar a influência de uma tarefa cognitiva cotidiana sobre a coativação muscular de mulheres idosas e jovens durante a marcha. Participaram do estudo 17 mulheres jovens fisicamente ativas e 18 mulheres idosas com baixo risco de quedas. Os voluntários foram orientados a caminhar sobre uma esteira em duas diferentes condições de marcha: marcha normal e marcha com dupla-tarefa cotidiana. Os sinais eletromiográficos foram coletados dos músculos dos membros inferiores. A porcentagem de coativação para tibial anterior/gastrocnêmio lateral e tibial anterior/sóleo foram significativamente maiores em idosos do que em jovens na marcha normal e marcha com dupla-tarefa. Nossos resultados sugerem que os idosos tem maior coativação muscular no tornozelo durante a marcha normal e marcha com dupla tarefa cotidiana. Assim, nós concluimos que situações cognitivamente desafiadoras durante a marcha podem aumentar o risco de quedas em idosos.

Palavras-chaves: idosos, marcha, coativação, quedas

Resumen-“Coactivación muscular del miembro inferior de jóvenes y ancianos saludables durante la marcha con doble tarea funcional." El objetivo de este estudio fue investigar la influencia de una tarea cognitiva diaria en la coactivación muscular en ancianos y jóvenes durante la marcha. Los participantes del estudio fueron 17 ancianos y 18 jóvenes físicamente activos con bajo riesgo de caídas. Los voluntarios caminaron sobre una cinta de correr en dos condiciones diferentes: la marcha normal y la marcha con doble tarea cotidiana. Las electromiografía se obtuvo de los músculos de las extremidades inferiores. El porcentaje de co-activación de los tibialis anterior/gastrocnemius lateralis and tibialis anterior/soleus fueron significativamente mayores en los ancianos que en los sujetos jóvenes durante la marcha normal y marcha con doble tarea. Nuestros resultados sugieren que los ancianos tienen un mayor coactivación muscular en el tobillo durante la marcha normal y marcha con doble tarea cotidiana. Por lo tanto, se concluye que las situaciones cognitivamente desafiantes durante la marcha puede aumentar el riesgo de caídas en los ancianos.

Palabras claves: ancianos, marcha, coactivación, caídas 


\section{Introduction}

Aging is related with changes in sensory and motor functions such as decreased muscle strength, flexibility, balance, proprioception, attention and reaction time (Bassey, 1997). These progressive declines can impair the ability to perform complex motor tasks and are associated with the high rates of falls among older adults (65 years of age or older) (Tinetti $\&$ Speechley, 1989). In the United States and Brazil, falls are the main cause of injuries among elderly people. Approximately $29 \%$ of the elderly population falling at least once a year, $14 \%$ of whom because recurrent fallers (Kirkwood,et al., 2011).

Falls are the main cause of injury and injury- related death among older adults accounting for about $45 \%$ of all deaths in this population (Schulz, Lloyd, \& William, 2010). In addition, falls contribute to health problems, decreased mobility, independence and quality of life, resulting in high medical and social costs (Van Dieen \& Pijnappels, 2008). The risk of falls is multifactorial and more than $50 \%$ of cases of older adult falls occur during the gait (Talbot, Musiol, Witham, \& Metter, 2005). Thus, the ability to walk efficiently and safely is important for the maintenance of independence and health by reducing the risk of falls (Callisaya, et al., 2010).

Older adults may use adaptive strategies to maintain the dynamic equilibrium during gait, such as reduced speed, stride length, swing phase duration and hip, knee and ankle movement amplitudes (Hortobagyi \& Devita, 2006). Thus, the biomechanical and physiological changes associated with aging can result in reduced functional capacity. Therefore, challenges encountered during the gait, which are easily overcome by young adults, may represent a potential risk for falls among older adults (Van Dieen \& Pijnappels, 2008; Bruijn, Van Dieen, Meijer, \& Beek, 2009).

Gait planning, regulation and performance requires high levels of dedicated attention and cognition (Lajoie, Teasdale, Bard, \& Fleury, 1993). Thus, when the gait is held in conjunction with the other cognitively demanding task, performance of both tasks can be impaired (Abbud, Li, \& Demont, 2009). Concomitantly performance of cognitive and motor tasks can change the postural control of older adults increasing the risk of falls (Schulz, et al., 2010).

Increased cognitive demands during walking may also result in neuromuscular changes such as increased muscle coactivation (Seidler, He, \& Stemach, 1998). Coactivation may be used to increase stiffness when older adults are exposed to balance disturbances (Cenciarini, Loghlin, Sparto, \& Redfern, 2010).

The assessment of lower limb muscle activity using surface electromyography can provide important information about the neuromuscular behavior during the gait and help determine risks and strategies to prevent falls (Schmitz, Silder, Heiderscheit, Mahoney, \& Thelen, 2009). The objective of this study was to evaluate lower limb muscle coactivation levels in healthy younger and older adults during normal and dual-task gait.

\section{Method}

\section{Participants}

Thirty-five physically active volunteers participated in the study, including 17 younger (22 \pm 2$)$ and 18 older women $(65 \pm 3)$. The younger women were recruited from a university setting and the older women were recruited from a community group of physical activity for older adults. All participating older women had low risk of falls based on the Berg Balance Scale (55 \pm 0.97$)$. The selected sample was female, because this population has a higher prevalence of falls than elderly males (Siqueira et al., 2011). The sample size was determined based on a pilot study data and using the program $\mathrm{G}^{*}$ Power (power $=0.95$, effect size $=1.21$, á error $=0.05$ ). Table 1 shows the characteristics of the study participants.

The exclusion criteria were having more than low risk of falls on the Berg Balance Scale, musculoskeletal pain, fractures or severe soft tissue injury during the prior 6 months, or neurological, cardiovascular or respiratory diseases. The volunteers who reported dizziness or discomfort during the tests, were asked to stop immediately and were excluded from the sample $(n=2)$. This study was approved by the local ethics committee and all participants signed an informed consent form (Ethics Committee approval 13/09/2009 - CEP 69/2009).

\section{Equipments}

The gait tests were performed on the motorized treadmill with adjustable speed of $0.36 \mathrm{~m} / \mathrm{s}$ Millennium Super ATL (INBRAMED ${ }^{\circledR}$ ).

The surface eletromyographic activity (EMG) was collected using an electromyographer $\left(\right.$ Noraxon $\left.^{\circledR}\right)$ and the software Myoresearch $\left(\right.$ Noraxon $\left.^{\circledR}\right)$.

The lower limbs motion in the sagittal plane was recorded using a digital camera (Panasonic ${ }^{\circledR}$ NVGS 320) operating a $100 \mathrm{fps}$. The kinematic data was analyzed using the software Vicon $^{\circledR} 9.0$ - (Peak Motus).

\section{Procedures}

Surface electrodes $\mathrm{Ag} / \mathrm{AgCl}\left(\right.$ Meditrace $^{\circledR}$ ) were used and positioned in bipolar configuration on the rectus femoris (RF) and biceps femoris (BF), vastus lateralis (VL) and BF, vastus medialis (VM) and $\mathrm{BF}$, tibialis anterior (TA) and gastrocnemius lateralis (GL), TA and soleus (SO) muscles, following the SENIAM guidelines (Hermens, Freriks, Disselhorst-Klug, \& Rau, 2000). The choice of the muscles was performed to obtain EMG recordings of agonists and antagonists of hip flexion, knee and ankle.

Reflective markers were used to indicate anatomical landmarks and positioned in right lateral malleolus, left medial malleolus and between the first and second metatarsals right and left.

Before beginning of the gait tests, the subjects performed a familiarization trial by walking on the treadmill at their self- 
Table 1. Characteristics of the sample ( $\mathrm{n}=35$ women).

\begin{tabular}{lccc}
\hline & Younger $(\mathrm{n}=17)$ & Older $(\mathrm{n}=18)$ & $P$ \\
\hline Age (year) & $21.47( \pm 2.06)$ & $65.33( \pm 3,14)$ & $<0.01 *$ \\
Weight $(\mathrm{Kg})$ & $60.68( \pm 5.93)$ & $64.00( \pm 1.55)$ & $<0.01 *$ \\
Height $(\mathrm{m})$ & $1.63( \pm 0.05)$ & $1.55( \pm 0.05)$ & $0.01 *$ \\
Preferred gait speed $(\mathrm{m} / \mathrm{s})$ & $0.95( \pm 0.84)$ & $0.70( \pm 1.92)$ & \\
\hline
\end{tabular}

*significant differences between the younger and older women groups $(p<0.05)$

determined preferred gait speed (Dingwell \& Marin, 2006). After the familiarization, the tests were completed during two different gait conditions: normal gait and functional dualtask gait.

During normal gait the volunteers were asked to walk on the treadmill at their preferred speed for three consecutive minutes. After the normal gait test, the functional dual-task gait test was completed at the preferred speed also for three minutes.

During the functional dual-task gait condition, the volunteers were told to walk on the treadmill at their preferred speed and at the same time pay attention to a mock traffic light which changed color randomly. When the lights changed color the volunteers had to say which color was lit.

\section{Data analysis}

EMG during the 10 initial gait cycles of both conditions was analyzed. The kinematic data was used to determine the gait cycles. Heel strike was defined as the point where the heel marker was at its most forward position during the gait cycle (Kang \& Dingwell, 2007). The EMG signals were recorded at $1000 \mathrm{~Hz}$ and processed using routines developed in MatLab ${ }^{\circledR}$ 7.0. The linear envelope EMG data from each muscle of each participant was interpolated at 1001 points on the ten gait cycles, and normalized by the mean EMG during the normal gait condition.

The percentage of agonist/antagonist coactivation for the muscles RF/BF, VM/BF, VL/BF, TA/GL and TA/SO was calculated using the following equation (Candotti et al., 2009):

$$
\% \mathrm{COACT}=2 . \text { common area } \mathrm{A} \& \mathrm{~B} .100
$$

Where \%COCON is the percentage of coactivation between the agonist/antagonist muscles; area $\mathrm{A}$ is the area below the processed EMG curve of muscle A; area B is the area below the processed EMG curve of muscle $B$, and common area $\mathrm{A} \& \mathrm{~B}$ is the common area of activity of muscles A and B (Figure 1) (Candotti, et al., 2009).

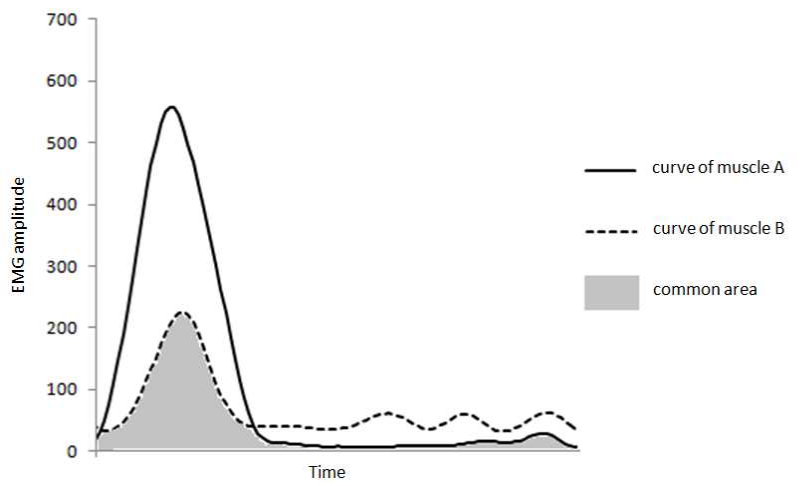

Figura 1. Common area A \& B is the common area of activity of muscles $\mathrm{A}$ and $\mathrm{B}$.

Descriptive statistics were calculated, and to compare muscle coactivation during the gait conditions, the Student $t$ test (within group) and the Student $t$ test for independent samples (between groups) were used. The significance level was set at $p<0.05$. All statistical analyzes were performed using the software PASW statistics 18.0 (SPSS.inc).

\section{Results}

Older women tended to have higher levels of coactivation than younger women for all muscles (Figure 2). However, the differences were only statistically significant for the TA/ GL and TA/SO pairs during normal gait condition ( $p=0.004$ and $p=0.004$, respectively) and during the dual-task gait condition ( $p=0.003$ for both). There was also a trend of increased levels of coactivation during dual-task gait than during normal gait. However, this trend was not statistically significant.

\section{Discussion}

In this study, older women tended to have higher levels of lower limb muscle coactivation than younger during 

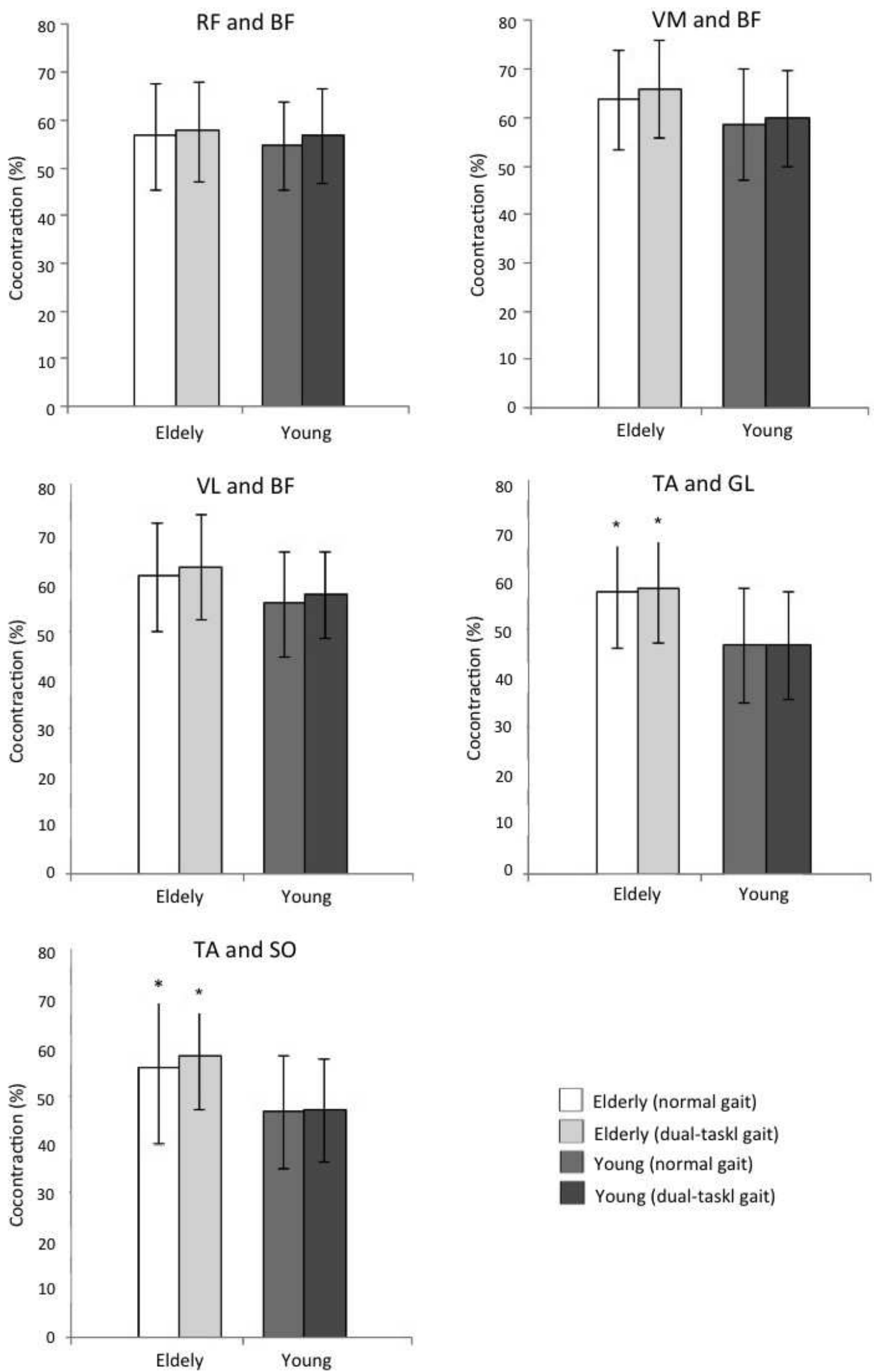

Figure 2. Percent of coactivation between rectus femoris (RF) and biceps femoris (BF), vastus lateralis (VL) and BF, vastus medialis $(\mathrm{VM})$ and $\mathrm{BF}$, tibialis anterior (TA) and gastrocnemius lateralis (GL), TA and soleus (SO) muscles in both gait conditions. ${ }^{*} p<0.05$ between older and younger women. 
normal and dual-task gait. The trends were statistically significant for the ankle muscles. Increased coactivation might be used to compensate for aging-related neuromotor functioning decline, such as reduced muscles strength and power, reduction in the proportion of fast twitch fibers and increased muscle response time, to optimize power generation (Mazzeo, Cavanagh, \& Evans, 1998; Ortega \& Farley, 2007; Ishida, Masuda, Inaoka, \& Fukuoka, 2008). Our findings support that older adults may indeed use higher levels of coactivation to compensate for the agingassociated declines on sensory and motor functioning to maintain stability.

Increased joint stiffness in older adults can be a strategy to increase the rigidity of the joints during the stance phase to compensate for reduced muscle strength and/or ligament laxity resulting from aging (Schmitz, Silder, Heiderscheit, Mahoney, \& Thelen, 2008). However, higher ankle muscle coactivations can cause unwanted compensations in the hip and knee, such as increased flexion at push-off (Kirkwood, et al., 2011).

The results also showed a trend of increased levels of coactivation during dual-task gait than during normal gait, which was particularly consistent among the older women. This trend was not statistically significant. However, future studies with larger samples and possibly less within group variability might find significant differences. The trend observed support the positive relationship between increased cognitive demands and increased levels of coactivation during gait. During the dual task gait condition, the older women seem to coactivate ankle muscles to enhance joint stiffness to maintain the dynamic equilibrium. However, increase in stiffness is not always a good response because it might contribute to increased risk of falls (Cenciarini, et al., 2010). It is possible that increased stiffness is only effective for slow balance perturbations, not being an effective strategy to deal with rapid disturbances, such as following a stumble during walking. Increase in stiffness can be an indicator of inefficiency and increased energy expenditure due to the coactivation of agonist and antagonist muscles (Candotti, et al., 2009). Thus, high percentages of coactivation can result in mechanical disadvantages, favoring the onset of fatigue, limiting the duration of activities, and increasing the risk of falls (Hortobágyi \& Devita, 2000; Ortega \& Farley, 2007).

The ankle muscles are essential for maintaining stability during walking; perfect timing of these muscles help to ensure a stable and secure gait (Neptune, Kautz, \& Zajac, 2001). Timing between plantar flexors and dorsiflexors activation at different gait phases is important, and particularly in the transition from mid stance to terminal stance to control the rotation of the tibia (Kirkwood, et al., 2011). Proper rotation of the tibia is essential for the maintenance of stability in unipodal stance. Changes in the activation of plantar flexor muscles in the elderly can reduce the rotation of the tibia, which compromises the stance phase and leading to an early push-off phase (Kirkwood, et al., 2011). As a result of these changes in muscle recruitment, compensations may occur such as decreased stride length, excessive knee flexion in early swing and reduction of anterior displacement of the body, which affects balance during gait (Perry \& Burnfield, 2006).

The influence of cognitive task on postural control is more pronounced when the level of task complexity is high (Swan, Otani, \& Loubert, 2007). In our study, the cognitive task performed while walking can be considered easy, this may have influenced the effect-size of the dual-task gait condition limiting our ability to identify significant differences. However, the choice of the mock traffic light paradigm as the basis for the dual-task condition was made because it is a commonly encountered situation during daily living representing a realistic and possible risk of falls. Significant differences might have been found if we had enroled a larger number of subjects and/or if we had less intra-group variability by recruiting participants that were more similar to each other on age, body mass, level of physical activity and other variables.

Strengthening and endurance programs for the elderly can minimize the effects of sarcopenia and improve ankle muscle performance (Morse, Thom, Mian, Birsh, \& Narici, 2007). Thus, we emphasize the importance of including ankle muscle activation retraining in older-adults falls prevention programs, as well as the inclusion of dual-task simulations which are similar to situations that are likely to be encountered in real life situations.

The preferred gait speed chosen by the older and younger women was significantly different. Thus, the mechanical challenge imposed on the joints of the participants may also have been different. Considering that the gait of older adults is commonly characterized by a greater neuromuscular demand and higher energy cost when performed at speeds similar to that used by young people, the preferred gait speed was used to be the approximate speed that each volunteer walks in their daily activities. Therefore, the preferred gait speed was considered optimal for the evaluation of changes in gait parameters performed with dual-task (Hortobagyi \& Devita, 2006; Ortega \& Farley, 2007).

The older women who participed in this study were physically active and were classified as having low risk of falls by the Berg Balance Scale. Considering that these factors may interfere with the performance the tasks evaluated and levels of co-contraction, studies with older adults who are sedentary and/or present increased risk of falls are recommended.

\section{Conclusions}

Older women tended to have higher levels of lower limb muscle coactivation than younger women during normal and dual-task gait than during normal gait, which was particularly consistent among the older women. Larger sample studies with less intra-group variability are required to evaluate these observed trends which may help to explain the high rates of falls among older adults and may assist on the establishment of prevention programs. 


\section{References}

Abbud, G. A. C., Li, K. Z. H., \& Demont, R. G. (2009). Attentional requirements of walking according to the gait phase and onset of auditory stimuli. Gait \& Posture, 30(2), 227-232. doi: 10.1016/j.gaitpost.2009.05.013.

Bassey, E. J. (1997). Physical capabilities, exercise and aging. Reviews in Clinical Gerontology, 7(4), 289-297. doi:10.1017/ S0959259897007429.

Bruijn, S. M., Van Diien, J. H., Meijer, O. G., \& Beek, P. J. (2009). Is slow walk more stable? Journal of Biomechanics, 42(10), 1506-1512. doi: 10.1016/j.jbiomech.2009.03.047.

Callisaya, M. L., Blizzard, L. S., Hmidt, M. D., Mcginley, J. L., \& Srikanth, V. K. (2010). Ageing and gait variability - a population - based study on older people. Age and Ageing, 39(2), 191197. doi:10.1093/ageing/afp250.

Candotti, C. T., Loss, J. F., Begatini, D., Soares, D. P., Rocha, E. K., Oliveira, A. R., \& Guimarães, A. C. S. (2009). Cocontraction and economy of triathletes and cyclists at different cadences during cycling motion. Journal of Electromyography and Kinesiology, 19(5), 915-921. doi: 10.1016/j.jelekin.2008. 04.008 .

Cenciarini, M., Loughlin, P. J., Sparto, P. J., \& Redfern, M. S. (2010). Stiffness and damping in postural control increased with age. IEEE Transactions on Biomedical Engineering, 57(2), 267-275. doi: 10.1109/TBME.2009.2031874.

Dingwell, J. B., \& Marin, L. C. (2006). Kinematic variability and local dynamic stability of upper body motions when walking at different speeds. Journal of Biomechanics, 39(3), 444-452. doi:10.1016/j.jbiomech.2004.12.014.

Hermens, J. H., Freriks, B., Disselhorst-klug, C., \& Rau, G. (2000). Development of recommendations for SEMG sensors and sensor placement procedures. Journal of Electromyography and Kinesiology, 10(5), 361-374. doi.org/10.1016/S10506411(00)00027-4.

Hortobágyi, T., \& Devita, P. (2000). Muscle pre-coactivity during downward stepping are associated with leg stiffness in aging. Journal of Electromyography and Kinesiology, 10(2), 117-126. doi.org/10.1016/S1050-6411(99)00026-7.

Hortobagyi, T., \& Devita, P. (2006). Mechanisms responsible for the age-associated increase in coactivation of antagonist muscles. Exercise and Sport Sciences Reviews, 34(1), 29-35. doi: 10.1016/s1050-6411(99)00026-7

Ishida, A., Masuda, T., Inaoka, H., \& Fukuoka, Y. (2008). Stability of the human upright stance depending on the frequency of external disturbances. Medical \& Biological Engineering \& Computing, 46(3), 213-221. doi: 10.1007/s11517-007-02698.

Kang, H. G., \& Dingwell, J. B. (2007). Separating the effects of age and walking speed on gait variability. Gait \& Posture, 27(4), 572-577. doi:10.1016/j.gaitpost.2007.07.009.

Kirkwood, R. N., Trede, R. G., Moreira, B. S., Kirkwood, S. A., \& Pereira, L. S.M. (2011). Decreased gastrocnemius temporal muscle activation during gait in elderly women with history of recurrent falls. Gait \& Posture, 34(1), 60-64. doi: 10.1016/ j.gaitpost.2011.03.012.

Lajoie, Y., Teasdale, N., Bard, C., \& Fleury, M. (1993). Attentional demands for static and dynamic equilibrium. Experimental Brain Research, 97(1), 139-144. doi: 10.1007/BF00228824.

Mazzeo, R. S., Cavanagh, P., \& Evans, W. J. (1998). Exercise and physical activity for older adults. Medicine and Science in Sports and Exercise, 30(6), 992-1008. doi:10.1249/mss.0b013e 3181a0c95c.

Morse, C. I., Thom, J. M., Mian, O. S., Birch, K. M., \& Narici,
M. V. (2007). Gastrocnemius specific force is increased in elderly males following a 12 -month physical training programme. Journal of Applied Physiology, 100 (5), 563-70. doi 10.1007/s00421-006-0246-1.

Neptune, R. R., Kautz, S. A., \& Zajac, F. E. (2001). Contributions of the individual ankle plantar flexors to support, forward progression and swing initiation during walking. Journal of Biomechanics, 34(11), 387-98. doi.org/10.1016/S00219290(01)00105-1.

Ortega, J. D., \& Farley, C. T. (2007). Individual limb work does not explain the grater metabolic cost of walking in elderly adults. Journal of Applied Physiology, 102(6), 2266-2273. doi 10.1152/ japplphysiol.00583.2006.

Perry, J., \& Burnfield. L. M. (2010). Gait analysis. Normal and pathological function. Thorofare: SLACK Incorporated. doi: 10.1001/jama.2010.1210.

Schmitz, A., Silder, A., Heiderscheit, B., Mahoney, J., \& Thelen, D. G.(2008). Differences in lower-extremity muscular activation during walking between healthy older and young adults. Journal of Electromyography and Kinesiology, 19(6), 1085-1091. doi 10.1016/j.jelekin.2008.10.008.

Schmitz, A., Silder, A., Heiderscheit, B., Mahoney, J., \& Thelen, D. G. (2009). Differences in lower-extremity muscular activation during walking between healthy older and young adults. Journal of Electromyography and Kinesiology, 19(6), 1085-1091. doi:10.1016/j.jelekin.2008.10.008.

Schulz, B. W., Lloyd, J. D., \& William, E. (2010). The effects of everyday concurrent task on overground minimum toe clearance and gait parameters. Gait \& Posture, 32(1), 18-22. doi: 10.1016/ j.gaitpost.2010.02.013.

Seidler, R. D., He, J., \& Stemach, G. E. (1998). Coactivation to reduce variability in the elderly. Motor Control, 2(4), 314315.

Siqueira, F. V., Facchini, L. A., Silveira, D. S., Piccini, R. X., Tomasi, E., Thume, E., Silva, S. M., \& Dilélio, A. (2011). Prevalence of falls in elderly in Brazil: a countrywide analysis. Cadernos de Saúde Pública, 27(9), 1819-1826. doi.org/10.1590/ S0102-311X2011000900015.

Swan, L., Otani, H., \& Loubert, P. V. (2007). Reducing postural sway by manipulating the difficulty levels of a cognitive task and a balance task. Gait \& Posture, 26(3), 470-474. doi org/ 10.1016/j.gaitpost.2006.11.201.

Talbot, L. A., Musiol, R. J., Witham, E. K., \& Metter, E. J. (2005). Falls in young, middle-aged and older community dwelling adults: perceived cause, environmental factors and injury. BCM Public Health, 5(1), 86-90. doi: 10.1186/1471-2458-5-86.

Tinetti, M., \& Speechley, M. (1989). Prevention of falls among the elderly. New England Journal of Medicine, 320(16), 10551059. doi: 10.1056/NEJM198904203201606.

Van Dieen, J. H., \& Pijnappels, M. (2008). Falls in older people. Journal of Electromyography and Kinesiology, 18(4), 169-171. doi: 10.1383/wohm.2006.3.4.173.

\section{Authors' note}

Camilla Zamfolini Halla, Nise Ribeiro Marques, Alex Castro and Adalgiso Coscrato Cardozo are affiliated with the Biomechanics Laboratory. São Paulo State University. Biosciences Institute IB/ UNESP. Rio Claro. SP. Brazil. Departament of Physical Education. São Paulo State University. Biosciences Institute IB/UNESP. Rio Claro. São Paulo. Brazil. 
Deborah Hebling Spinoso is with the Biomechanics Laboratory. São Paulo State University. Biosciences Institute IB/UNESP. Rio Claro. SP. Brazil. Departament of Physiotherapy. São Paulo State University. UNESP. Presidente Prudente. São Paulo. Brazil.

Mauro Gonçalves is affiliated with the Biomechanics Laboratory. São Paulo State University. Biosciences Institute IB/UNESP. Rio Claro. SP. Brazil. Departament of Physical Education. São Paulo State University. Biosciences Institute IB/UNESP. Rio Claro. São Paulo. Brazil. Departament of Physiotherapy. São Paulo State University. UNESP. Presidente Prudente. São Paulo. Brazil.

Edgar Ramos Vieira and Denis Brunt are affiliated with the Departament of Physical Therapy. Florida International University, Miami, USA.

\section{Acknowledgements}

The authors wish to thanks the funding providing by FAPESP, $\mathrm{CNPq}$ and Fundunesp.

\section{Correspondence}

Camilla Zamfolini Halla

Biomechanics Laboratory. São Paulo State University.

Biosciences Institute IB/UNESP

Av. 24A, $\mathrm{n}^{\circ} 1515$, CEP 13506-900, Rio Claro, SP, Brazil

email: camillazhallal@yahoo.com.br

Phone: 17-81043145

This study was presented at the $8^{\text {th }}$ International Congress of Physical Education and Human Movement and $14^{\text {th }}$ Symposium Paulista Physical Education.

Declaration of Conflicting Interests: The authors declared no conflicts of interest exist with respect to the research, authorship, and/or publication of this article.

Manuscript received on March 30, 2013

Manuscript accepted on May 8, 2013 